\title{
THE ANALOGUES OF TENSE INTERPRETATION IN RUSSIAN EMBEDDED CLAUSES: ABSOLUTE VS. RELATIVE MODALITY, ABSOLUTE VS. RELATIVE ASPECT $^{1}$
}

\author{
Letuchiy A. B. (alexander.letuchiy@gmail.com) \\ National Research Unviersity Higher School of Economics, \\ Moscow, Russia
}

The paper adresses parallels between tense, aspect and modality marking in Russian embedded clauses. It is widely known that tense forms of embedded verbs can be interpreted relatively or absolutely, and in some cases, the relative and absolute use seem to be in free variation. It turns out that the interpretation of modality and aspect can be described along the same lines and classified into the relative and absolute uses. For instance, subjunctive mood-one of the main instruments of irreality marking-can be interpreted as less real than the main event (relative interpretation) or less real than the moment of speech (and to the same degree as the main event; absolute interpretation). Similarly, aspect forms, depending on their interpretation, can describe the structure of the situation compared to the speech act or to the main event. I show that the parallelism between the three categories is not full: for instance, relative modality is mainly observed in triclausal constructions. Modality interpretation is sensitive to the opposition of clausal adjuncts vs. relative clauses. For the aspect interpretation, the contrast between finite forms and infinitive is relevant: infinitive allows for relative use of perfective aspect use much easier than finite forms. Finally, interpretations of the three categories are related to each other. For example, in complement clauses, the relative interpretation is perfectly acceptable for all the three categories.

Key words: relative tense, modality, aspect, complement clause, adjunct clause, relative clause, triclausal construction, infinitive

DOI: $10.28995 / 2075-7182-2020-19-1065-1077$

1 This study was supported by grant \#17-29-09154 from the Russian Foundation for Fundamental Research. 


\title{
ОТНОСИТЕЛЬНОЕ ВРЕМЯ \\ И ЕГО АНАЛОГИ: ОТНОСИТЕЛЬНАЯ МОДАЛЬНОСТЬ И ОТНОСИТЕЛЬНЫЙ ВИД
}

\author{
Летучий А. Б. (alexander.letuchiy@gmail.com) \\ Национальный исследовательский университет \\ Высшая школа экономики, Москва, Россия
}

\begin{abstract}
В докладе рассматриваются параллели между маркированием в русских подчинённых клаузах времени, модальности и вида. Широко известно, что время в подчинённых клаузах может иметь абсолютную или относительную интерпретацию, и иногда, например, в некоторых конструкциях с сентенциальными актантами, эти варианты взаимозаменимы. Мы предполагаем, что те же варианты интерпретации существуют для вида и модальности. Например, сослагательное наклонение может маркировать модальность относительно главной ситуации (тот факт, что ситуация менее реальна, чем главная по отношению к ней) или модальность относительно речевого акта. Точно так же аспект может выражать аспектуальные характеристики ситуации по отношению к речевому акту или к главной ситуации.
\end{abstract}

Ключевые слова: относительное время, вид, модальность, сентенциальные актанты, сентенциальные сирконстанты, сентенциальные определения, триклаузальная конструкция, инфинитив

\section{Introduction}

In the studies of Russian tense, one of the most salient problems is the problem of relative vs. absolute tense interpretation. It turns out that in subordinate clauses, the tense form can be used and interpreted absolutely (and denote the event temporal localization with respect to the speech act) or relatively (and denote the event temporal localization with respect to the main event)—see [Barentsen 1995], [Khomitsevich 2007], [Say 2016], [Schnittke 2020] with the analysis of Russian, and [Klecha 2018] for similar issues in English. In (1), the two variants can refer to the same situation where both situations, 'surprise' and 'behave', occur simultaneously. In this case, the present tense form vedet 'behaves' is interpreted relatively ('simultaneously to the main event'), and the past tense form vel 'behaved' absolutely ('before the speech act').

(1) Меня удивляло, что Петя так себя ведёт / вёл.

Note that the problem is particularly intriguing because the relative and absolute interpretation do not correspond to any systemic morphological distinction. The same forms can be interpreted either relatively or absolutely, depending on the context. In the talk, I will consider these notions in more detail and show that similar oppositions are relevant for modality and aspect. Since for modality and aspect the notion 
of temporal localization is irrelevant, I propose the following generalized definition for absolute vs. relative tense, aspect and mood (also known as TAM categories):

- Absolute interpretation of a TAM category = interpretation in which the particular grammatical value is interpreted with respect to the speech act;

- Relative interpretation of a TAM category = interpretation in which the particular grammatical value is interpreted with respect to the main event (event in the main clause).

It should be explicitly mentioned that Russian does not distinguish absolute vs. relative mood and aspect by means of grammatical forms - the situation is the same here as with tense forms. The same forms of tense, mood and aspect can be interpreted relatively or absolutely.

\section{Modality}

As [Plungyan and van der Auwera 1998] show, modality distinguishes two main groups of meanings:

(i) Reality of situations (epistemic modality)

(ii) Evaluation of the situation, relations between the situation and the speaker / hearer / participants of the situation (deontic / internal modality) ${ }^{2}$

For instance, in the epistemic meaning of high probability (group (i)) John must already be there denotes that the situation 'John is there' is very close to reality, though is not necessarily true. In the meaning of internal possibility (group (ii)), such as John must work harder, the construction with must denote the relation between the participant John and the situation 'work harder', namely, John's duty to work harder.

The reality status is mainly relevant for the first type of modality. The question that has not acquired much attention in previous linguistic work is how the irrealis applies to complex sentences, in particular, how it interacts with embedded clauses. Consider the following example: someone knows that John will often go to Canada next three years. He tells John:

\section{(2) Bring something to me when you go to Canada.}

In (2), the first part Bring something to your mother is marked with imperative and is irreal: John has not promised to bring any souvenirs to his mother, and it is only the speaker's wish for him to do so. By contrast, the second part is real: it is known that John will go to Canada. The reality of this situation follows partly from the fact that kogda-clauses are by default factive: if it is said that ' $\mathrm{X}$ will happen when $\mathrm{Y}$ happens' then the speaker believes that $Y$ happens (though, of course, factivity can be weakened by the imperative context). The first part is a part of assertion, not of presupposition, and the addressee can object the speaker's opinion saying that X will not happen.

\footnotetext{
2 Throughout the paper, I ignore the notion of 'neutral modality' which is sometimes postu-
} lated for epistemic contexts, e.g., for constructions with matrix verbs like dumat' 'think'. 
A more complicated question is how to mark the configuration when both events are unreal and is in the scope of imperative, something like 'I want you to go to Canada and to bring something to your mother'. It seems that the English construction with when does not allow us to do so. Another embedded clause type with Russian esli or English if is not factive but does not put the embedded clause in the imperative scope: the only thing it marks is that the given state of affairs is possible. To mark the meaning required, the construction should be radically changed to yield Please go to Canada and bring something to your mother. In Section 2.1, 2.2 and 2.3, I will consider the same problem for Russian. I will show that modality (more precisely, irreal mood forms) is sometimes expressed in the embedded clauses but the possibility of this type of constructions depends upon the clause type.

\subsection{Relative vs. absolute modality}

In what follows, I discuss the opposition of the absolute vs. relative mood interpretation. When applied to modality, the notion of absolute / relative interpretation is understood in the following way:

- Absolute interpretation of a modal form: the modal form denotes the reality status of the situation compared to the speech act;

- Relative interpretation of a modal form: the modal form denotes the reality status of the situation compared to the main event.

For instance, If the subjunctive mood form in the embedded clause is interpreted relatively, we expect that the reality status is counted based on the status of the upper clause. Since subjunctive is a mood form with irreal meaning, the relatively interpreted subjunctive form means that the situation is less real / more irreal than the situation in the upper clause. By contrast, if the subjunctive mood form is interpreted absolutely, it only means that the situation in the embedded clause is less real than the reality (the speech act situation is always real) - however, it can have the same reality status as the situation in the upper clause. The distinction we observe is similar to the opposition of relative vs. absolute tense. In tense opposition, the embedded tense form can mark the time of the event based on the time of the speech act or the main event. In modality context, the reality status of the embedded event can be marked with respect to the main even of the speech act.

For instance, if I imagine a situation that I lived in Germany and it made me angry that my salary was used to provide loafers with money, and I describe the situation as in (3), I use a relative modality in the final clause:

(3) Кстати, меня бы, живи я в Германии, думаю, бесило бы, что половина моего заработка уходит на бездельников...

Only in the main clause is the verb marked for the irrealis (subjunctive) (besilo by $)^{3}$. The embedded verb uxodit also denotes an unreal event. However, this irreality

3 [Brecht 1977] and [Dobrushina 2012] show that by inside the marker čtoby behaves as a part of word, and not an autonomous particle. At the same time, syntatically, by inside ćtoby is a part of the subjunctive form because čtoby is only compatible with infinitives and l-forms. 
is ignored, and the verb is marked with indicative past as belonging to the same reality plan as the matrix verb ponjal. In (4), all verbs are marked for subjunctive, but the modality in the third clause is also relative. It denotes that the third clause belongs to the unreal world introduced by the second verb xotel (which, in turn, belongs to the world introduced by the subordinator udivilsja) — thus, the subjunctive uvolili is, so to say, second order irrealis, it denotes an event shifted to 'more unreal' world than the second event esli by Vasja xotel 'if Vasja wanted':

(4) Я бы удивился, если бы Вася хотел, чтобы его уволили.

The absolute modality is illustrated by (5). The subjunctive perestali (by) in the third clause is not introduced by the verb nastal (by) in the second one: the form perestali by does not mean that the situation in the third clause is more compared to the situation in the second clause. Both subjunctive forms denote events belonging to the same world and introduced by the main verb xotel - thus, they have the same reality status. Thus, the modality marking is absolute here: the form perestali by means that the event is irrreal compared to the speech act:

(5) Я бы хотел, чтобы настал момент, когда мы перестали бы воевать.

If we imagine that the modality is marked relatively in the last clause of (5), the reality status being compared to the upper clause nastal moment 'the time would come'. In this case, an indicative form would be expected in the last clause (e.g., perestanem '(we) will stop') because the reality status of the event in the last clause corresponds to the same world as in the second clause (čtoby nastal moment 'that the time came'), and no shift to more unreal world is observed in the last clause.

Constructions with absolute modality like (5) can be called 'mixed constructions'. The term means that, on the one hand, they contain an irreal marker by, and, on the other hand, the embedding marker they contain (kogda, čto) mainly have a 'real' semantics.

In some respects, the distribution of relative vs. absolute modality is similar to the distribution of tense interpretations. For instance, complement clauses bear relative mood marking, which is not necessary the case for clausal adjuncts and relative clauses. At the same time, some parameters responsible for mood reading distribution are not repeated in the tense domain. Below I consider only two of them: oppositions of adjunct vs. relative clauses and propositional vs. conditional contexts.

\subsection{Adjunct clauses vs. relative clauses}

In the tense domain, adjunct and relative clauses are similar to each other. For both of them, absolute tense is the default way of marking:

(6) Я встретил человека, который жил в соседнем доме.

(7) Я встретил его, когда он работал на телевидении.

4 Of course, another reading where Vasja has already been robbed is also available. In this case, the reading of indicative mood is absolute and counted from the speech act ( $=$ the real situation). 
In some relative or adjunct clauses, past tense can be replaced with present, but they either do not have an interpretation or their meaning is different from the one they had previously. For instance, in (6), the change of žil to živet will change the meaning from 'the person who previously lived there' to 'the person who lives there now, at the speech time' (thus, the present tense will be interpreted absolutely).

Rather unexpectedly, in the mood domain, adjunct and relative clauses behave differently. The latter show absolute mood marking (reality status with respect to the speech act) more readily than the former. For instance, examples like (8) are more widespread than (9):

(8) Я бы хотел, чтобы настал момент, когда мы перестали бы воевать.

(9) Я бы хотел, чтобы мы туда пришли, когда перестали бы воевать.

Why do the two clause types differ in the mood marking? If we consider their behavior in biclausal structures, we will find some other differences. [Dobrushina 2012] describes a special subjunctive subtype of Russian relative clauses. They are usually used when the relativization target refers to a non-specific entity that may not exist or, if it exists, the speaker cannot distinguish it from other similar objects:

(10) Я ищу человека, который наладил бы мне компьютер.

No similar structure exists for adjunct clauses. For instance, (10') could theoretically be used in the sense 'the time when $\mathrm{X}$ occurs, given that this time may be nonexistent'. However, the example is ungrammatical:

(10’) *Я туда приду, когда бы позволила ситуация.

'I will come there when the situation allows.'

This difference shows that the relative clause in Russian tends to mark the modal meanings in relative clauses more explicitly than in adjunct clauses. ${ }^{5}$

\subsection{Propositional contexts vs. conditional contexts}

Another borderline lies between propositional contexts (i.e., use of irreal form in the complement position of matrix verbs like xotet' 'want', prikazat' 'order' and others) and conditional contexts (use of irreal forms postulated by the general conditional cotnexts).

[Esli by on ustroilsja na rabotu v Rosatom.]

(11) Я бы ему говорил, чтобы он там работал, пока его бы не уволили.

(12) *Я ему говорил, чтобы он там работал, пока его бы не уволили.

In spite of the similarity between examples (11) and (12), the former is significantly better than the latter. The reason is that in (11), the general conditional context supposes the irreality. In this case, absolute tense use is facilitated and the subjunctive

5 Note that an alternative variant $Я$ бы туда пришёл, когда позволила бы ситуация is possible, but it is not parallel to (10) where the main clause contains an indicative form. 
form is anchored to the external context. By contrast, in the hypothetic example (12), the (almost unacceptable) subjunctive form in the deepest clause should be licensed by the verb govoril in the matrix clause, it is an absolute form that has the same reality status as rabotal. As noticed before, the absolute modal use is problematic in complement clauses. The difference between conditionals and propositional contexts may result from a different place in the system that the two types of forms have. In propositional contexts (12), the mixed construction can be easily replaced with a future form with a relative interpretation. By contrast, irrealis in conditional contexts like (11) is linked to the general rule of tense use in conditional constructions (in the irreal context, subjunctive forms must be used in both parts of the construction) and does not have any concurring strategy.

At the same time, even in conditional contexts, absolute modality is restricted. If Clause 2 (below C2) contains a factive epistemic verb (e.g., ponjat' 'understand', znat' 'know'), absolute unreal marking in the subordinate clause C3 is problematic:

(13) ??Он бы понял, что его бы обманули.

But if C2 contains a factive emotional predicate like besit' 'drive crazy', the embedded complement clause can contain an absolute modality:

(14) но его бы бесило, что она пыталась бы на его бунтарскую натуру воздействовать... (www.diary.ru/ L Logovojuni)

(15) ... а будь я игроманом (назовём так), мне бы не понравилось, что меня бы тащили на приём к врачу (tlttimes.ru/blog/family)

In (14) and (15), the embedded event (ona by pytalas' 'she would try', menja by taščili 'they would make me go') belongs to the same world as the main one (ego by besilo 'It would make him angry', mne by ne ponravilos' 'I wouldn't like it'). Thus, the subjunctive in the embedded clause is absolute, it denotes the irreality of the event with respect to the speech act. ${ }^{6}$

\section{Relative vs. absolute aspect}

\subsection{Opposition of absolute vs. relative aspect}

The relative vs. absolute opposition is also relevant for the aspect, though in this case, the opposition is manifested in a different form. The problem of aspect in embedded clauses has been discussed in linguistics for a long time, e.g. by [Forsyth 1970], but no attention was given the absolute vs. relative distinction. I propose the following definitions for absolute and relative interpretations of aspect:

6 We are grateful to an anonymous reviewer who points to the fact that (13) can be improved by adding a precondition as that existing in (15) (bud' ja igromanom 'if I was a computer game addict'). However, to my intuition, adding a precondition does not make (13) significantly better. 
Absolute interpretation of an aspectual form: the choice of the aspectual from in the embedded clause reflects the relations between the embedded situation and the speech act.

Relative interpretation of an aspectual form: the choice of the aspectual form in the embedded clause reflects the structural isomorphism between the main and the embedded situation.

The speech act can be regarded as a single processual event: it is not repeated, and the situation in which communication takes place has temporal duration. Thus, the absolute interpretation can be regarded as an interpretation that compares the properties of the embedded situation to a single processual event. By contrast, under the relative interpretation in which aspectual properties of the embedded situation are compared to those of the main one the type of interpretation depends both on the properties of the main and of the embedded situation.

For instance, the aspect in (16) is relative:

(16) Он часто заходил в банк, чтобы снять деньги с карты.

The embedded form is perfective but refers to multiple event. Thus, it cannot be anchored to the speech act, because the speech act is not multiple, and there is no isomorphism between the speech act and the repetitions of the embedded clause. In this case, we could not interpret the perfective form as a repeated event designation. The point is that the aspect form in the embedded clause is interpreted relatively: the main event is also repeated ('often came'), and the perfective form in the embedded clause denotes that each of the repetitions of the event is linked to one occurrence of the main event. The perfective in the multiple interpretation denotes isomorphism between the repetitions of the main and the embedded event. Thus, the anchor for aspect marking is the main situation zaxodil 'came': if the embedded situation is observed from the main situation zaxodil, each iteration of the main situation has a corresponding embedded one: each time when the subject comes, he withdraws money only once. If the interpretation of the repeated situation of money withdrawal was anchored to the speech act, the imperfective form snimat' 'withrdaw' would be expected here.

By contrast, in (17), the imperfective form in the temporal clause is interpreted absolutely. The verb zabolevat' (the imperfective form) is chosen because the properties of the embedded event is directly compared to the speech act properties, thus, the repeatedness of the embedded event contrasts with the fact that the speech act is a single event. To mark this contrast, the imperfective form is used. Under the relative interpretation, the verb 'fall ill' had to be in the perfective form zabolet', because it is a punctual event taking place once each time when most people come to the hospital. ${ }^{7}$

(17) он даже сам ко мне приходит, когда заболевает...

(https://www.liveinternet.ru/users/oleg 376/post329977161/play)

7 Of course, the choice of the imperfective form in (17) can simply explained by the fact that the event is repeated or habitual. However, this explanation does not help us in addressing the fact that in (16), the perfective aspect form is chosen for a repeated event. 
The opposition of the relative vs. absolute aspect interpretation correlates with taxis, however, this correlation is not so strict. For instance, tense in (17) is absolute, as well as aspect. Under the relative interpretation, the present tense form is used to mark the simultaneity of the two events. The fact that in (17), the imperfective form is used to mark precedence (the person spoken about falls ill before he visits the doctor) shows that the present tense is absolute in (17): it denotes only the temporal relation between an event and the speech act, but not between the two events. Below I give example showing that the interpretations of categories are not independent from each other. In (18), the clausal complement is used with a relative tense, and the aspect form will also be relative:

(18) \#Серёжа каждый раз понимал, что ему всё равно будут посылать рекламу (но всё равно давал свой е-мэйл).

(18) is possible, but only in the sense that the sending of advertisement will take place multiply and the acts of sending are not distributed by the cases when Serezha understands it. In this case, the relative and absolute aspect interpretations are indistinguishable since we do not know if the interpretation of the imperfective form budut posylat' '(they) will send'is anchored to the speech act or to the main situation. By contrast, the diagnostic meaning when one act of sending advertisement corresponds to one understanding case (the main and the embedded situations are 'paired'. This situation can only be referred to with (19):

(19) Серёжа каждый раз понимал, что ему пошлют рекламу (но всё равно давал свой е-мэйл).

The fact that the same meaning is unavailable for (18) shows that the interpretations of tense and aspect should preferably correspond each other. The fact that blocks the relevant (paired) interpretation in (18) is that future tense budut posylat' in (18) (just as pošljut in (19)) is relative: both forms fix the location of event with respect to the main event ponimal 'understood' (the context shows that both situations are situated before the speech act, e.g., in the absolute past). The relative reading of tense is incompatible with the absolute reading of aspect, and imperfective in (18) would require the absolute reading with respect to the speech act. By contrast, in (19), the perfective form pošljut has a relative reading (each occurrence of the repeated embedded situation corresponds to one occurrence of the repeated main situation). This relative aspect reading corresponds well to the relative tense reading.

At the same time, there are many 'neutralization contexts' where aspect, tense or both of them can have either of the two interpretations, as in (20):

(20) Потом я, конечно, сожалел, что әто делал.

In (20), the imperfective form can have two readings:

(i) 'Afterwards, I was sorry that some days ago I used to do it multiply.' [The past tense and the imperfective aspect can be absolute or relative, the main and the embedded event are regarded as single, repetitions do not count]. 
(ii) 'Each time I did it I was sorry afterwards' [The past tense can be absolute or relative, the imperfective aspect is absolute, because each act of being sorry is linked to one bad action].

\subsection{The role of finiteness}

Aspect differs from the other two categories (mood and tense) in that the relative interpretation is easier with infintive than with finite forms. For instance, with the subordinator posle togo kak, compatible with finite forms, relative aspect is impossible (21); with pered tem kak 'before' it is possible if infinitive is used (moreover, the infinitive pattern seems incompatible with imperfective, as in (23)), and if infinitive is changed to a finite form, the relative aspect marking is obligatorily changed to the absolute one (22):

(21) Он всегда к нам заходил после того, как возвращался / "вернулся.

(22) Он всегда к нам заходил перед тем, как уезжал / "уехал.

(23) Он всегда к нам заходил перед тем, какуехать / “уезжать.

To see the difference, we should speak about the reading of (21)-(23) where both the matrix and the embedded situation are repeated. In other words, there are multiple situations where the subject leaves somewhere, and in each of these situations, he visits the speaker's family. In (21) and (22), where the finite forms vozvraščalsja '(he) used to return' and uezžal '(he) used to leave' are used, the absolute form use is the default one: the imperfective form marks the repeatedness of the situation compared to the speech act which is a single situation. By contrast, in (23), containing an infinitive form uexat' 'leave', normally, the perfective form in the relative interpretation is chosen. The embedded situation is also repeated, thus, the use of perfective can only be explained by the fact that the structure of the embedded situation is described as parallel to the main situation (each iteration of the main event corresponds to one iteration of the embedded event, described, thus, as a single event and marked with perfective). Note that infinitive in purpose clauses is also used primarily in the relatively interpreted perfective.

The reason of this behavior of infinitive is not entirely clear. However, most probably, the reason is that infinitive is tighter integrated into the main clause structure than finite embedded clauses are. ${ }^{8}$ And, which is related to the previous fact, infinitive has a lesser number of own syntactic and semantic properties than finite clauses have (e.g., infinitives are unmarked for tense and do not usually have their own subject). The relative aspect marking should presumably be regarded as another manifestation of the fact that infinitives are not autonomous from the main clause: the aspect choice in infinitive clauses is based on the properties of the situation in the main clause.

8 This fact is supported by multiple syntactic tests, such as (1) impossibility of reflexive binding across the border of finite clauses and possibility of their binding across the border of infinitive clauses; (2) impossibility of negative concord across the border of finite clauses and possibility of NC across the border of infinitive clauses, and so on. 


\section{Conclusions}

In this paper, I tried to show that the well-known contrast of relative vs. absolute tense-marking finds parallels in the aspect and modality domains. Although Russian has no specialized forms expressing only relative or only absolute tense, aspect or modality, all the three TAM categories have two possible interpretations: each of them can be anchored to the speech act or to the the main event. Of course, the parallel does not mean identity of categories: for instance, tense can be represented as a temporal scale, while aspect and modality are hardly representable as a 'scale of reality' and 'scale of aspectual structure'. In fact, the concrete rules of interpretation of tense, mood and aspect have something in common. For instance, in complement clauses tense, modality and aspect tend to be interpreted relatively-though this tendency is weaker for tense, for which the relative interpretation is only the default one, but usually not the single variant, and stronger for modality and aspect (for these categories, the change of the relative use to the absolute one sometimes leads to ungrammaticality).

In adjunct clauses, by contrast, mood and aspect become less strict than tense. For tense, absolute interpretation is almost obligatory for many types of adjunct clauses. By contrast, for both modality and aspect, relative interpretation is sometimes possible (for mood, it is partially available in relative clauses, while for aspect, in infinitive clauses with the purpose and temporal meaning, e.g., with the subordinator pered tem kak).

At the same time, due to the formal and semantic differences between these categories and ways of their expression the distinction manifests in different ways. For instance, the modality expression shows an additional distinction between 'general irreal contexts' (contexts where a long part of the narrative belongs to the possible world, as in the conditional construction) and 'propositional contexts' where the situation or complex of situations is a content of someone's wish, speech, cognitive act, emotion, and so on, and the wish, speech or emotion itself belong to the real world. Another relevant parameter is the opposition of adjunct clauses where mood interpretation is usually relative and relative clauses where it can be absolute.

For aspect, the special feature is the relevance of the finiteness for the use of grammatical values. Infinitive is easier compatible with relative interpretation (the infinitive clause embedded under a construction with imperfective with a repeated event reading is normally marked with perfective, because each iteration of the main event corresponds to one iteration of the embedded event). By contrast, finite embedded clauses tend to include absolutely interpreted verb forms, thus, the repeated event in the embedded clause is normaly denoted by an imperfective, just as the repeated event in the main clause).

I suppose that the interpretation of the three categories in one context should be similar (it is mainly the case that either all the three categories are interpreted relatively or all of them ais re interpreted absolutely). When tense is interpreted relatively, absolute interpretation of aspect is also problematic. However, checking and explaining this tendency should be a topic of future studies.

Table 1 summarizes the distribution of absolute and relative interpretations. 
Table 1. Contexts of relative and absolute interpretation of tense, aspect and modality

\begin{tabular}{|l|l|}
\hline \multicolumn{2}{|c|}{ TENSE } \\
\hline complement clauses & $\begin{array}{l}\text { both relative and absolute are possible, } \\
\text { but relative is the main variant }\end{array}$ \\
\hline adjunct clauses & mainly absolute, very rarely relative \\
\hline relative clauses & mainly absolute, very rarely relative \\
\hline \multicolumn{2}{|c|}{ ASPET } \\
\hline complement clauses & mainly relative, rarely absolute \\
\hline adjunct clauses with finite forms & mainly absolute, rarely relative \\
\hline adjunct clauses with infinitives & mainly relative, rarely absolute \\
\hline \multicolumn{2}{|c|}{ MODITY } \\
\hline $\begin{array}{l}\text { conditional context: complement } \\
\text { clauses }\end{array}$ & $\begin{array}{l}\text { mainly relative, rarely absolute (abso- } \\
\text { lute mainly with emotional predicates) }\end{array}$ \\
\hline conditional context: adjunct clauses & mainly absolute, rarely relative \\
\hline conditional context: relative clauses & both relative and absolute are possible \\
\hline $\begin{array}{l}\text { propositional context: complement } \\
\text { clauses }\end{array}$ & almost exlusively relative \\
\hline propositional context: adjunct clauses & mainly relative, rarely absolute \\
\hline propositional context: relative clauses & both relative and absolute are possible \\
\hline
\end{tabular}

\section{References}

1. van der Auwera J., Plungian V. (1998), Modality's semantic map, Linguistic Typology, 1998, Vol. 1(2), pp. 79-124.

2. Barentsen A. (1995), Shifting points of orientation in Modern Russian: Tense selection in 'reported perception', T. Janssen \& W. Van Der Wurff (eds.), Reported speech: Form and functions of the verb, Amsterdam \& Philadelphia, John Benjamins, pp. 15-55.

3. Brecht R. (1977), Čtoby or čto and by, Folia Slavica, Vol. 1, pp. 33-41.

4. Dobrushina N. R. (2010), Subjunctive in Russian relative clauses, Oslo Linguistic Studies, Vol. 2. No 1, Russian in contrast. Grammar, A. Grønn and I. Marijanovic (eds.), pp. 181-210.

5. Dobrushina N. R. (2012), Subjunctive complement clauses in Russian, Russian linguistics, Vol. 36 (2), pp. 121-156.

6. Forsyth J. (1970), A grammar of aspect: Usage and meaning in the Russian verb. Cambridge University Press, Cambridge, MA.

7. Khomitsevich O. (2007), Dependencies across phases. From sequence of tenses to restrictions on movement, Utrecht, LOT Publications, Utrecht University Dissertation.

8. KlechaP. (2018), A formal pragmatic account of double access, available at https://semanticsarchive.net/sub2018/Klecha.pdf. 
9. Padučeva E. V. (2014), Ėkspletivnoe otricanie isemantika sojuza poka [Expletive negation and the meaning of the subordinator poka], V. A. Plungjan, M. Danièl', E. A. Ljutikova, S. G. Tatevosov \& O. V. Fedorova (eds.), Language. Language. Constants. Variables. In memory of Alexander Evgen'jevich Kibrik. [Jazyk. Konstanty. Peremennye. Pamjati Aleksandra Evgen'eviča Kibrika], Moscow, Aleteja, pp. 339-350.

10. Say S. S. (2016), Tense in Russian finite complement clauses: neutralization and reference point [Vremja v russkix finitnyx sentencial'nyx aktantax: nejtralizacija i točka otsčeta], Proceedings of Institute of Russian Language of RAS [Trudy Instituta russkogo jazyka RAN], Vol. 10, pp. 256-275.

11. Schnittke E. L. (2020), Towards the problem of sequence of tenses in modern Russian: A corpus study of distributional characteristics of tense forms in complement clauses [K voprosu o soglasovanii vremen v sovremennom russkom jazyke: Korpusnoe issledovanie distributivnyx xarakteristik vremennyx form v sentencialnyx aktantax], Issues in linguistics [Voprosy jazykoznanija], Vol. 3, pp. 26-51. 